\title{
Rhodococcus equi által okozott nagyízületi endoprotézis körül kialakult fertőzés
}

\author{
Sallai Imre dr. ${ }^{1}$ - Péterfy Nóra dr. ${ }^{2}$ - Mohammad Sanatkhani dr. ${ }^{3}$ \\ Bejek Zoltán dr. ${ }^{1}$ - Antal Imre dr. ${ }^{1}$ - Prinz Gyula dr. ${ }^{4}$ \\ Kristóf Katalin dr. ${ }^{5}$. Skaliczki Gábor dr. ${ }^{1}$ \\ ${ }^{1}$ Semmelweis Egyetem, Általános Orvostudományi Kar, Ortopédiai Klinika, Budapest \\ ${ }^{2}$ Szent János Kórház, Traumatológiai és Kézsebészeti Osztály, Budapest \\ ${ }^{3}$ Regionális Fogorvosi Centrum, Pest Megye, Cegléd \\ ${ }^{4}$ Egyesített Szent István és Szent László Kórház, IV. Fertőző Belgyógyászati Osztály, Budapest \\ ${ }^{5}$ Semmelweis Egyetem, Általános Orvostudományi Kar, \\ Klinikai Mikrobiológiai Diagnosztikai Laboratórium, Budapest
}

\begin{abstract}
A Rhodococcus equi ritka patogén, amely fóként gyengült immunrendszerű vagy immunszupprimált betegekben okoz fertőzést. Esetbemutatásunkban Rhodococcus equi által okozott nagyízületi endoprotézis körül kialakult fertőzést mutatunk be, amelynek leírására még nem volt példa a nemzetközi irodalomban. A 88 éves férfi beteget láz és jobb oldali csípőfájdalom miatt vettük fel klinikánkra. A beteg anamnézisében több, mindkét oldalt érintő csípőmútét szerepelt, és a jobb oldalon aszeptikus lazulás miatt korábban revíziós arthroplastica is történt. Ismert betegségei között szerepelt cukorbetegség, diabeteses nephropathia, valamint korábbi stroke miatt bal oldali hemiplegia, azonban kifejezett immunszuppresszió nem. A képalkotó vizsgálatok a jobb oldali csípőprotézis komponenseit stabilnak mutatták, az ízületi punkcióból pedig Rhodococcus equi tenyészett ki. A betegnek azonnali feltárást és a protézis körüli terület tisztítását javasoltuk, amit visszautasított. Konzervatív kezelést, parenteralis antibiotikum-terápiát kezdtünk. A beteg gyulladásos paraméterei csökkentek, fájdalma megszűnt. Esettanulmányunk célja, hogy a nagyízületi protézisek szeptikus komplikációi kapcsán felhívjuk a figyelmet a ritka patogének növekvő szerepére.

Orv Hetil. 2017; 158(27): 1071-1074.
\end{abstract}

Kulcsszavak: Rhodococcus equi, periprotetikus fertőzés, ritka kórokozó

\section{Periprosthetic joint infection caused by Rhodococcus equi}

\section{Case report}

Rhodococcus equi is a rare pathogen in humans causing infections mostly in immunocompromised hosts. We present the first case of periprosthetic joint infection caused by Rhodococcus equi. An 88-year-old male patient was referred to our clinic with a history of fever and right hip pain. The patient had multiple hip surgeries including total joint arthroplasty and revision for aseptic loosening on the right side. He was immunocompetent, but his additional medical history was remarkable for diabetes mellitus, diabetic nephropathy and stroke with hemiplegia resulting in immobilization. Radiography showed stable components, joint aspirate yielded Rhodococcus equi. Irrigation and debridement was proposed, but the patient refused any surgical intervention. Therefore antibiotic therapy was administered. At the last follow-up the patient is free of complaints but the C-reactive protein level is still elevated. This case illustrates the possible role of Rhodococcus equi in medical device-associated infections.

Keywords: Rhodococcus equi, periprosthetic joint infection, rare pathogen

Sallai I, Péterfy N, Sanatkhani M, Bejek Z, Antal I, Prinz Gy, Kristóf K, Skaliczki G. [Periprosthetic joint infection caused by Rhodococcus equi. Case report]. Orv Hetil. 2017; 158(27): 1071-1074. 
A protézisgyártók fejlesztéseinek és a mútéti technika folyamatos fejlődésének köszönhetően, a teljes felszínpótló nagyízületi endoprotézisek beültetése napjainkra biztonságos, nagy sikerrátájú beavatkozásokká váltak, hosszú távú megoldást biztosítva a betegek fájdalmas mozgásszervrendszeri panaszaira. A mútét előtti bakteriális góc kutatása, valamint a perioperatív és korai posztoperatív szakban alkalmazott, világszerte elterjedt biztonsági beavatkozások, mint például a mútő́ben használt lamináris légáramoltató rendszerek, a profilaktikus antibiotikum használata a szeptikus szövődmények kialakulásának csökkenését eredményezték. Mindezek ellenére a nagyízületi felszínpótló protézisek 2-3\%-ánál szeptikus szövődmény alakul ki, amely veszélybe sodorja a protézis hosszú távú túlélését. A periprotetikus fertőzések diagnosztikája mind a mai napig kihívás elé állítja az ortopéd sebészeket. A kórokozó precíz meghatározása a további kezelés szempontjából meghatározó jelentőségü.

$\mathrm{Az}$ alacsony virulenciájú, aerob, Gram-pozitív coccobacillus, a Rhodococcus equi az állatgyógyászatban jól ismert patogén, amely fóként a fiatal csikók tüdőtályogosodással járó bronchopneumoniáját (csikók mirigykórját) okozza [1]. Az első humán fertőzésrôl 1967-ben számoltak be [2], az ez után következő 15 évben összesen 12 másik esetet ismertettek. A HIV terjedésétól kezdve egyre gyakrabban diagnosztizálták, legtöbb esetben immunhiányos állapotban lévő betegeken, például szervtranszplantáltaknál és daganatos betegeknél [3]. Gyógyászatban használt implantátumokkal összefüggésben csak kevés publikáció született $[4,5]$. Mozgásszervrendszeri sebészetben használt implantátumhoz társuló fertőzésrôl pedig, tudomásunk szerint, eddig még nem számoltak be.

\section{Esetismertetés}

A 88 éves férfi beteget jobb oldali csípótáji fájdalom miatt vettük fel klinikánkra. Ezt megelőzően három hétig otthonában magas láza $\left(38,9^{\circ} \mathrm{C}\right)$ és influenzaszerú tünetei voltak. A betegnél korábban számos alkalommal végeztünk csípőmútétet. Teljes felszínpótló csípőízületi protézis beültetése 1998-ban a bal oldalon, majd 2000ben a jobb oldalon történt. 2005-ben a bal oldalon esést követôen periprotetikus törés miatt nyílt feltárást, repozíciót, lemezes osteosynthesist végeztünk cerclage-dróttal kiegészítve. Jobb oldalon 2011-ben aszeptikus protézislazulás miatt revíziós mútétet végeztünk, 2012-ben pedig a bal oldalon kialakult aszeptikus lazulás miatt került sor protéziscserére.

A beteg korábbi kórtörténetéből kiemelendőek a következő betegségek: mélyvénás thrombosis, diabetes mellitus, diabeteses nephropathia, valamint stroke, aminek következtében bal oldalon hemiplegia alakult ki. A beteg visszaemlékezése szerint jobb csípőjét trauma nem érte. Fizikális vizsgálat során mérsékelt tachycardiát észleltünk, kóros szívhangok nélkül. A hasi szervek vizsgálata nem mutatott eltérést, tüdőfolyamatra utaló kóros eltérés a tüdő vizsgálata során nem volt. A jobb csípő mozgásai beszúkültek, fájdalmasak voltak, a korábbi mútéti metszésnek megfelelő területen gyulladásra utaló jel, sipolynyílás nem volt látható.

Laborvizsgálatok gyorsult süllyedést (We: $77 \mathrm{mmol} / \mathrm{l}$ ), emelkedett CRP-értéket (CRP: $25,74 \mathrm{mg} / \mathrm{L}$ ), enyhe normocyter anaemiát $(\mathrm{Hgb}: 116 \mathrm{~g} / \mathrm{L})$ mutattak. A jobb oldali csípőboól kevés gennyes ízületi folyadékot nyertünk, amit mikrobiológiai vizsgálatra küldtünk. Az elkészült röntgenfelvételeken a protézis körül lazulásra utaló radiológiai jel nem volt látható. A klinikai kép késői akut haematogen szórás következtében létrejött periprotetikus infekciónak felelt meg. Ezt követően a betegnek mútéti feltárást, a műtéti terület átöblítését, a seb tisztítását, kimetszését ajánlottunk fel, a protézis eltávolítása nélkül, azonban a beteg a feltárásba nem egyezett bele. Felvételekor szulfamethoxazol/trimethoprim (Sumetrolim $400 \mathrm{mg}$ szulfamethoxazol/80 mg trimethoprim) és rifampicin (Rifamed - $300 \mathrm{mg}$ ) empirikus terápiát indítottunk. Ezt követôen láztalanná vált, de a CRP-értékek továbbra is emelkedettek maradtak, legmagasabb értéke: $47 \mathrm{mg} / \mathrm{L}$ volt.

A felvételkor vett ízületi mintából Rhodococcus equi tenyészett ki, amelynek azonosítása a klasszikus mikrobiológiai jellemző́k vizsgálata (növekedési jellemzők, katalázpozitivitás, CAMP-teszt-pozitivitás) mellett MALDI-TOF HS (Bruker) tömegspektrométerrel történt. A kórokozó érzékeny volt erythromycinre, vancomycinre, szulfamethoxazol/trimethoprimre, rifampicinre, doxycyclinre, rezisztens volt penicillinre, kinolonokra, valamint gentamicinre. Mivel a per os kezelés mellett gyulladásos értékei nem csökkentek megnyugtató mértékben, ezért infektológiai konzílium alapján a szulfamethoxazol/trimethoprim, rifampicin per os terápiát parenteralis vancomycinre váltottuk és további két hétig folytattuk a kezelést. A beteg panaszai gyorsan enyhültek, a CRP-érték is csökkent (CRP: $26 \mathrm{mg} / \mathrm{L}$ ). $\mathrm{Az}$ ismételt ízületi mintavételból baktérium nem tenyészett ki. Háromhetes antibiotikum-kezelést követően otthonába engedtük, ahol a kórházban korábban megkezdett orális antibiotikum-kezelést (szulfamethoxazol/ trimethoprim, rifampicin) javasoltuk, de a beteg javaslatunk ellenére már nem folytatta. Sajnálatos, hogy a beteg a kórházban alkalmazott antibiotikum-kúrán kívül minden egyéb terápiás javaslatot visszautasított. A három hónapos kontrollvizsgálaton a beteg láztalan volt, jobb csípője nem fájt, CRP-je továbbra is emelkedett (CRP: $28 \mathrm{mg} / \mathrm{L}$ ) volt, a röntgenfelvételek implantátumlazulás jeleit nem mutatták.

\section{Megbeszélés}

A Rhodococcus equi egy aerob, Gram-pozitív, fakultatív patogén coccobacillus, amely spórát nem képez. Az állategészségügyi mikrobiológiában jól ismert [6]. Az első humán megbetegedést 1967-ben jelentették egy autoimmun hepatitisben szenvedő betegnél, akit im- 
munszuppresszív szerekkel kezeltek (magas dózisú prednizolon és 6-merkaptopurin [6-MP]) [2]. A R. equifertőzés többségében immunszupprimált betegeket érint, ezért növekvő jelentőséggel bír, az utóbbi három évtizedben a HIV-fertőzés elterjedése, a fejlett rákgyógyítási módszerek, valamint a szervátültetések miatt [3, 7]. A $R$. equi-fertőzés ép immunrendszerü betegeknél nem túl gyakori [8], a leírt esetek csak mintegy 10-15\%ában fordul elö, és főleg a tüdőt érinti. Az extrapulmonalis előfordulás még ennél is ritkább, fóleg a központi idegrendszert, a bőrt és a csontokat támadja, az elsődleges tüdőfertőzés késői manifesztációjaként. Betegünk immunszuppresszív kezelést nem kapott, fennálló immunhiányos állapotáról nem volt tudomásunk, de az időskor, a diabetes és a stroke következtében kialakult csökkent mobilizálhatóság fogékonnyá tehették a kórokozóval szemben. Anamnézisét alaposan áttekintve korábbi tüdőgyulladásra utaló adatot nem találtunk. Gundelly és mtsai közleményében saját, 12, Rhodococcus equivel fertőzött eseteiket hasonlították össze az irodalomban fellelhető összes, 137 esettanulmánnyal. Főbb megállapításaik között szerepel, hogy az immunszupprimált betegeknél az irodalomban 95-100\%-os gyakorisággal fordult elő tüdőt érintő folyamat. Saját beteganyagukat elemezve: 12 esetből nyolc immunszupprimált beteg mindegyikénél előfordult tüdőérintettség. Ép immunrendszerü beteg Rhodococcus equi-fertőzése esetében dominálóan az extrapulmonalis megjelenés figyelhető meg, mindössze 50\%-uknál figyeltek meg tüdőérintettséget. Fontos megjegyezni tehát, hogy ép immunrendszerü betegek esetében a tüdőt érintő folyamat (tüdőgyulladás, tüdőtályog) megjelenése nem kell, hogy az egyéb szervben megjelenő fertőzést megelőzze, valamint nem csak a tüdőből kiindulva, véráram útján tud terjedni a kórokozó [9].

A R. equi-fertőzés forrása legfóképpen állatállománynyal vagy mezőgazdasági tevékenységgel kapcsolatos. Por belégzése által tüdőn keresztül, nyílt sebeken keresztül vagy a bélnyálkahártyán át szívódik fel. Humán kolonizációját, emberről emberre terjedő közvetlen átfertőződését is megfigyelték [3]. A mi esetünkben a fertőzés forrása nem tisztázott. Sem betegünk, sem családtagjai nem kerültek állatokkal kontaktusba.

A R. equi kezelési protokolljára vonatkozóan kevés információ áll rendelkezésünkre. A publikációk két-három antibiotikum kombinált adását javasolják, mert fennáll a veszélye a rezisztencia kialakulásának [10]. Elsőként választandó antibiotikumok közé tartozik az erithromycin, ciprofloxacin, vancomycin, imipenem vagy aminoglikozidok. Az intracelluláris aktivitással rendelkező antibiotikumok szerepe (például: rifampicin, azithromycin) nem tisztázott. A nemzetközi irodalomban találunk javaslatot az alkalmazásukra a $R$. equi intracelluláris túlélésének csökkentésére, míg más közlemények ennek a jelentőségét kétségesnek tartják [11].

Az abscessusok drenálása az antibiotikumok számára nehezen elérhető helyeken is javítja a gyógyulás esélyét.

Stabil implantátumok esetében a fertőzés korai szakaszában történő debridement és az intermittáló magas nyomású átmosás elsőrendű fontosságú a késői akut haematogen periprotetikus fertőzések kezelésében. Ez a beavatkozás 45-55\%-ban oldja meg a panaszokat [12]. Sajnos, a mi esetünkben sem a sebészeti beavatkozást, sem a 6-10 hétre kiterjedő antibiotikum-terápiát nem tudtuk maradéktalanul alkalmazni.

Kevés, orvosi implantátumhoz kötődő $R$. equi-fertőzésről számol be a nemzetközi irodalom. Scotton és mtsai által közölt esetben egy 51 éves nőbetegnek, akinek baleset során elszenvedett koponyatrauma következtében kialakult, CT-vel igazolt, bal oldali os occipitale törés és bal kisagyfél mellett kialakult haematoma (amely enyhén nyomta az agytörzset) miatt külső kamrai söntöt ültettek be. A kezelés az állapotát átmenetileg javította, azonban két hét után állapotrosszabbodást, szeptikus lázmenetet tapasztaltak, a kontroll-CT-vizsgálat kialakult hydrocephalust igazolt. A kialakult szeptikus állapot gócának a behelyezett kamrai sönt bizonyult. Kezelése során a fertőzött sönt cseréje, valamint vancomycin és rifampicin kombinált parenteralis terápia történt, azonban ez a beteg állapotán nem javított, így levofloxacin- (500 mg iv. naponta kétszer) monoterápiára váltottak. A beteg maradványtünet nélkül gyógyult [5].

Chan és mtsai hatéves utánkövetési időszak alatt 126 keratoprotézis-beültetést végeztek, amelyek közül tíz esetben tapasztaltak fertőzéses szövődményt. Ezek közül két esetben Rhodococcus equi okozta a fertőzést. A beültetés után elhúzódó lokális profilaktikus vancomycin- és moxifloxacinkezelést javasolnak, azonban, ha fertőzéses szövődményt észlelnek, felmerül a keratoprotézis eltávolítása vagy cseréje [4].

Legjobb tudomásunk szerint ez az első leírt, R. equi által okozott, mozgásszervrendszeri implantátumhoz kötődő periprotetikus fertőzés. Ezzel szeretnénk felhívni a figyelmet az implantátumok körül kialakuló fertőzésekben az alacsony virulenciájú kórokozók növekvő szerepére a mozgásszervrendszeri sebészetben.

Anyagi támogatás: A szerzók anyagi támogatásban nem részesültek.

Szerzői munkamegosztás: S. I., P. N., M. S.: A beteg kórtörténeti adatainak összegyújtése, esetbemutatás megírása. B. Z.: A beteg kezelőorvosa. S. G., A. I.: A kézirat előkészítése, lektorálása. P. Gy.: A kezelési stratégia kidolgozása. K. K.: A kórokozó azonosítása.

Érdekeltségek: A szerzőknek nincsenek érdekeltségeik. 


\section{Irodalom}

[1] Magnusson H. Spezifische infektiose Pneumonie beim Fohlen: ein neuer Eitererreger beim Pferd. Arch Wiss Prakt Tierheilk. 1923; 50: 22-38. [German]

[2] Golub B, Falk G, Spink WW. Lung abscess due to Corynebacterium equi. Report of first human infection. Ann Intern Med. 1967; 66: 1174-1177.

[3] Weinstock DM, Brown AE. Rhodococcus equi: an emerging pathogen. Clin Infect Dis. 2002; 34: 1379-1385.

[4] Chan CC, Holland EJ. Infectious keratitis after Boston type 1 keratoprosthesis implantation. Cornea 2012; 31: 1128-1134.

[5] Scotton PG, Tonon E, Giobbia M, et al. Rhodococcus equi nosocomial meningitis cured by levofloxacin and shunt removal. Clin Infect Dis. 2000; 30: 223-224.

[6] Walsh RD, Schoch PE, Cunha BA. Rhodococcus. Infect Control Hosp Epidemiol. 1993; 14: 282-287.

[7] Guerrero MF, Ramos JM, Renedo G, et al. Pulmonary malacoplakia associated with Rhodococcus equi infection in patients with AIDS: case report and review. Clin Infect Dis. 1999; 28: 13341336.
[8] Kedlaya I, Ing MB, Wong SS. Rhodococcus equi infections in immunocompetent hosts: case report and review. Clin Infect Dis. 2001; 32: e39-e46.

[9] Gundelly P, Suzuki Y, Ribes JA, et al. Differences in Rhodococcus equi infections based on immune status and antibiotic susceptibility of clinical isolates in a case series of 12 patients and cases in the literature. BioMed Res Int. 2016; 2016: 2737295.

[10] Yamshchikov AV, Schuetz A, Lyon GM. Rhodococcus equi infec tion. Lancet Infect Dis. 2010; 10: 350-359.

[11] Prescott JF. Rhodococcus equi: an animal and human pathogen. Clin Microbiol Rev. 1991; 4: 20-34.

[12] Romanò CL, Manzi G, Logoluso, N, et al. Value of debridement and irrigation for the treatment of peri-prosthetic infections. A systematic review. Hip Int. 2012; 22(Suppl 8): S19-S24.

(Sallai Imre dr., Budapest, Üllői út 78/B II. emelet, 1082 e-mail: sallai0limre@gmail.com; sallai.imre@semmelweis-univ.hu)

\section{MEGHÍVó}

\section{ROMHÁNYI ORVOSTALÁLKOZÓ}

Lelkigyakorlat (manreza) orvosoknak

Helyszín: SZÁR - Római katolikus templom

Időpont: 2017. szeptember 2.

\section{Fontos információk!}

Részvételi szándékát szíveskedjék augusztus 20 -ig jelezni

Koltayné Bartha Magdánál a 06-70/350-2062 telefonszámon vagy

a baratikor.saar@gmail.com e-mail címen.

Kérjük, hogy amennyiben lehetősége van rá, támogassa rendezvényünket a Szár Község Német Kisebbségi Oktatásáert és Kultúrájáért Egyesület (UniCredit Bank 10918001-00000036-60180000) részére átutalt vagy a helyszínen kapható csekken befizetett összeggel, „Romhányi Orvostalálkozó” megjegyzéssel.

\section{Program:}

\section{9:00 Szentmise}

10:00 Üdvözlések

Moharos Péter, polgármester

Prof. Dr. Kellermayer Miklós: Titkok bizonyossága a tudomány csúcsa

10:30 Udvardy György pécsi megyéspüspök: Egészség, ember, megváltás

11:00 Dr. Derényi Gábor, (a MOK FMSz elnöke): Az igaz példa

11:30 Prof. Dr. Szelényi Zoltán: Johann Sebastian Bach lutheránus miséiről a Reformáció jubileuma jegyében

14:00 Prof. Dr. Matolcsy András: A patológia oktatásának kihívásai a 21. században - Romhányi professzor nyomdokában

14:30 Prof. Dr. Csókay András: Idegsebészet és hétköznapi misztika

15:00 Prof. Dr. Kerpel-Fronius Sándor: Klinikai vizsgáló csoportokban együttmüködő nem orvos képzettségü kutatók etikai felelőssége

15:30 Prof. Dr. Pintér András: Hippocrates vagy Taigetos: etikai dilemmák az újszülött-sebészetben

Moderátor: Szelényi Zoltán egyetemi tanár, emeritus professzor 